\title{
Intracellular reactive oxygen species production and phagocytosis of Staphylococcus aureus by milk neutrophils as tool to diagnose mastitis and identify susceptible dairy cows ${ }^{1}$
}

\author{
Paula C.C. Molinari²*, Maiara G. Blagitz², Alice M.M.P. Della Libera², \\ Camila F. Batista ${ }^{2}$ and Fernando N. Souza ${ }^{2}$
}

\begin{abstract}
Molinari P.C.C., Blagitz M.G., Della Libera A.M.M.P, Batista C.F. \& Souza F.N. 2018. Intracellular reactive oxygen species production and phagocytosis of Staphylococcus aureus by milk neutrophils as tool to diagnose mastitis and identify susceptible dairy cows. Pesquisa Veterinária Brasileira 38(4):659-664. Veterinary Clinical Immunology Research Group, Departamento de Clínica Médica, Faculdade de Medicina Veterinária e Zootecnia, Universidade de São Paulo, Avenida Prof. Dr. Orlando Marques de Paiva 87, Cidade Universitária, São Paulo, SP 05508-270, Brazil. E-mail: paula.molinari@icloud.com

The immune response capacity of the mammary gland plays a major role to determine if mastitis will or not be established. Thus, we hypothesize that a better understanding of polymorphonuclear neutrophil leukocyte (PMN) function will elucidate mechanisms that will improve our knowledge of how we could avoid an inflammatory process by increasing the immune capacity of the cow, and even further, to search for a tool to diagnose mastitis or a possible way to select and identify non-susceptible animals. The present study utilized 112 quarters from 28 Holstein dairy cows that were divided into quarters milk samples with somatic cell

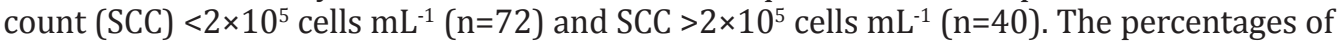
milk PMNs and the levels of intracellular reactive oxygen species (ROS) and the phagocytosis of Staphylococcus aureus by milk neutrophils were evaluated by flow cytometry. Our results showed a higher percentage of neutrophils in quarter milk samples with high SCC ( $P=0.0003)$, and this group also had a significantly higher percentage of neutrophils that produced ROS $(P=0.008)$. On the other hand, the phagocytosis intensity of $S$. aureus by milk neutrophils was higher in quarters with low SCC $(P=0.003)$, suggesting a better mammary gland immunity against invading pathogens. Analyzing the results of the predictive values of the measured PMN functions, they cannot be used isolated as a good diagnosis test since none of them had a satisfactory sensitivity and specificity values, which was also confirmed by the Youden index values being far from one. In conclusion, the assessment of milk bovine neutrophil functions could improve our understanding of the cellular basis of mastitis. Although, the intracellular ROS production and S. aureus phagocytosis by milk neutrophil did not have high predictive values to detect intramammary infections, our results strengthen the idea that that poor bovine mammary gland neutrophil phagocytic ability may be associated with high SCC, and might be considered to identify susceptible dairy cows to mastitis.
\end{abstract}

INDEX TERMS: Intracellular reactive, oxygen production, phagocytosis, Staphylococcus aureus, milk neutrophils, mastitis, dairy cows, intramammary infection, sensitivity, specificity, udder health status, immune response, cattle, bacterioses.

\footnotetext{
${ }^{1}$ Received on May 28, 2017.

Accepted for publication on June 14, 2017.

${ }^{2}$ Veterinary Clinical Immunology Research Group, Departamento de Clínica Médica, Faculdade de Medicina Veterinária e Zootecnia, Universidade de São Paulo, Avenida Prof. Dr. Orlando Marques de Paiva 87, Cidade Universitária, São Paulo, SP 05508-270, Brazil. *Corresponding author: paula.molinari@icloud.com
}

RESUMO.- [Produção intracelular de espécies reativas de oxigênio e fagocitose de Staphylococcus aureus por neutrófilos lácteos como ferramentas para o diagnóstico da mastite e identificação de vacas leiteiras susceptíveis à mastite.] A resposta imune da glândula mamária desempenha um papel importante ao determinar o estabelecimento da 
infecção. Desta forma, a melhor compreensão da função dos neutrófilos irá nos subsidiar conhecimentos, pelo qual podemos evitar o processo inflamatório pela otimização da resposta imune de bovinos leiteiros, e fornece ferramentas para diagnosticar a mastite ou um possível instrumento para identificar e selecionar animais resistentes à infecção intramamária, aumentando a produtividade do rebanho. 0 presente estudo utilizou 112 amostras provenientes de quartos mamários de 28 vacas Holandesas que foram divididos em amostras de leite com baixa $\left(\mathrm{n}=72 ;<2 \times 10^{5}\right.$ células $\left.\mathrm{mL}^{-1}\right)$ ou alta $\left(\mathrm{n}=40 ; 2 \times 10^{5}\right.$ células $\left.\mathrm{mL}^{-1}\right)$ contagem de células somáticas (CCS). A porcentagem de neutrófilos no leite, a produção intracelular de espécies reativas de oxigênio (ERO) e a fagocitose de Staphylococcus aureus pelos neutrófilos do leite foram avaliadas por citometria de fluxo. Os resultados do presente estudo demonstraram maior percentagem de neutrófilos ( $\left.\mathrm{CH} 138^{+} ; P=0,0003\right)$ e percentagem de neutrófilos que produziram ERO $(P=0,008)$ em amostras de leite com alta CCS. Por outro lado, a intensidade de fagocitose de $S$. aureus por neutrófilos em amostras de leite com baixa $\operatorname{CCS}(P=0,003)$, que demonstra maior atividade funcional destas células neste grupo. As funções neutrofílicas para o diagnóstico da mastite não apresentaram valores de sensibilidade e especificidade altos, que foram confirmados pelo índice Youden. Desta forma, conclui-se que a produção intracelular de ERO e fagocitose de $S$. aureus pelos neutrófilos do leite não apresentaram valores preditivos altos para detecção de mastite. Além disto, os resultados do presente estudo reforçam a ideia de neutrófilos do leite com menor capacidade fagocítica podem ser associados à alta CCS, e pode ser considerado como uma ferramenta para identificar animais mais susceptíveis à infecções intramamárias.

TERMOS DE INDEXAÇÃO: Produção intracelular, oxigênio, fagocitose, Staphylococcus aureus, neutrófilos lácteos, mastite, vacas leiteiras, infecção intramamária, sensibilidade, especificidade, saúde da glândula mamária, resposta imune, bovinos, bacterioses.

\section{INTRODUCTION}

Mastitis is the inflammatory process of the mammary gland, generally due to bacterial infection, and may spread to the other cows in the herd. It is a disease of major economic importance, due to the reduced milk yield and quality, and also the increasing use of veterinary drugs worldwide. Furthermore, the impact of mastitis must be highlighted due their public health and well-being standpoints. This infection can be diagnosed by the clinical symptoms as local pain, swelling, redness and milk alteration; however, these signals may not be present in the most common form of bovine mastitis, the subclinical mastitis. Thus, the milk somatic cell count (SCC) has long been used as an indicator of inflammation to diagnosis mastitis. With this in mind, there is a consensus that a quarter with a SCC above $2 \times 10^{5}$ cells $\mathrm{mL}^{-1}$ is usually considered infected (Schukken et al. 2003, Della Libera et al. 2011). However, is already stated that some animals may have an increased physiologic SCC value, which can mislead the interpretation of SCC results (Laevens et al. 1997).

In a healthy cow's milk the majority of somatic cells are macrophages and some polymorphonuclear neutrophils (PMN), epithelial and lymphocytes are also presented (Blagitz et al. 2015). In a case of intrammamary infection, as in mastitis, the level of neutrophils increases from $11 \%$ (healthy quarter) up to $90 \%$ (Pyörälä 2003, Mira et al. 2013), which makes the percentage of neutrophils in the SCC a potential mastitis indicator. It has already been suggested that a differential cell counting would provide more information about the udder health status than a simple SCC (Koess \& Hamann 2008, Mira et al. 2013).

Regarding that, the PMN migration into the mammary gland provides the first line of defense against mastitis pathogens. The PMN is a highly active cell so shortly after the migration of PMN to mammary gland, if it continually stays in the milk this phagocyte starts to change morphology and decrease its function as it englobes fat globules and casein. Thus, the prolonged exposure to milk compounds reduces the PMN capacity to produce reactive oxygen species (ROS) and phagocytosed pathogens, what means that milk PMN are less responsive to pathogens since they have already been activated by the milk compounds (Paape et al. 2003). In face of, as milk neutrophils are largely recruited during infection, we speculated that the neutrophil functions can be used to diagnose mastitis.

Although, there are many studies that proved the difference between phagocytosis activity by milk neutrophils, their phagocyte function is far from being completely understood. This study evaluated the bactericidal capacity of these milk neutrophils using a specific marker $\left(\mathrm{CH} 138^{+}\right)$to get evidences to comprehend the immune response. The $\mathrm{CH} 138 \mathrm{~A}$ is a primary anti-bovine granulocyte monoclonal antibody used to differentiate milk PMNs from other cells by indirect fluorescent labeling. This staining pattern shows both high sensitivity and specificity (Piepers et al. 2009), allowing the distinction of labeled PMNs from other milk cells and particles. The use of this marker avoid erroneous identification of PMNs compared to the use of the granularities (SSC) and size (FSC) characteristics of PMNs to identify this cell population by flow cytometry.

The immune response capacity of the mammary gland plays a major role to determine if mastitis will or not be established. Thus, we hypothesize that a better understanding of PMN function will elucidate mechanisms that will improve our knowledge of how we could avoid an inflammatory process by increasing the immune capacity of the cow, and even further, to search for a tool to diagnose mastitis. Our goal is go even more and identify not only the subclinical mastitis but to select and identify resistant animals, increasing the herd productivity.

\section{MATERIALS AND METHODS}

Animals and experimental design. The present study utilized 112 quarters from 28 Holstein dairy cows were collected at various stages of lactation from a commercial herd located at Tambaú, São Paulo State, Brazil, between the months of May and August 2010. No samples from dairy cows in the immediately post-partum were used. The herds underwent machine milking, and the following mastitis control practices for milking were adopted: forestripping in a strip cup to check for clinical mastitis, pre-dipping, and drying teats with a paper towel. After milking, post-dipping was also used. Dry cow therapy and clinical mastitis treatments were also adopted. The milk samples were divided into two groups: (1) quarters with SCC $\leq 2 \times 10^{5}$ cells $\mathrm{mL}^{-1}$, which is the milk SCC threshold proposed by Schepers et al. (1997) and Schukken et al. (2003) for uninfected quarters, and (2) quarters with SCC $>2 \times 10^{5}$ cells $\mathrm{mL}^{-1}$. All quarters exhibited no abnormal secretion in the strip cup test. All animals 
received the same basal diet, formulated to meet their requirements (NRC 2001). This research complied with the Ethical Principles for Animal Research and was approved by the Bioethics Commission of the Faculdade de Medicina Veterinária e Zootecnia from Universidade de São Paulo (Protocol No. 1685/2009).

Sample collection. First, the strip cup test was performed to identify the presence of clots, flakes or otherwise obviously abnormal secretions. Then, the pre-dipping was performed, and one towel was used for each teat. After discarding the first three milk streams, milk samples for the SCC (approximately $40 \mathrm{~mL}$ ) and evaluation of neutrophilic function (approximately $200 \mathrm{~mL}$ ) were collected. Samples were kept at $4^{\circ} \mathrm{C}$ for about three hours until arriving at the laboratory. Milk samples for bacteriological analysis were cooled at $-20^{\circ} \mathrm{C}$ until the analysis.

Determination of the somatic cell count (SCC). Milk samples for SCC were collected in $40 \mathrm{~mL}$ vials containing microtablets of bronopol (2-bromo-2-nitropane-1,3-diol) as a preserving agent. Subsequently, SCC measurements were performed using an automated, fluorescent, microscopic somatic cell counter (Somacount 300 - Bentley Instruments ${ }^{\circledR}$, Chaska, USA).

Bacteriological analysis. The bacteriological analysis was performed by culturing $0.01 \mathrm{~mL}$ of each single milk-quarter sample on $5 \%$ bovine blood agar plates. The plates were incubated for 72 hours at $37^{\circ} \mathrm{C}$, followed by Gram staining, observation of the colony morphology and biochemical testing (Oliver et al. 2004).

Separation of milk cells. The separation of the milk cells was performed as described by Koess \& Hamann (2008). Briefly, 200mL of milk was diluted with $200 \mathrm{~mL}$ of phosphate-buffered saline (PBS; $\mathrm{pH}$ 7.4; $1.06 \mathrm{mM} \mathrm{Na}_{2} \mathrm{HPO}_{4}, 155.17 \mathrm{mM} \mathrm{NaCl}$ and $2.97 \mathrm{mM} \mathrm{Na}_{2} \mathrm{HPO}_{4} .7 \mathrm{H}_{2} \mathrm{O}$ ). After centrifugation at $1,000 \mathrm{xg}$ for $15 \mathrm{~min}$, the cream layer and supernatant were discarded. The cell pellet was then washed once using $30 \mathrm{~mL}$ of PBS and centrifuged at $400 \mathrm{xg}$ for $10 \mathrm{~min}$. The cells were resuspended in 1mL of RPMI-1640 nutritional medium (cat. No. R7638, Sigma Aldrich, USA) supplemented with 10\% fetal bovine serum (Cultilab, Campinas, Brazil) and counted using a Neubauer chamber. Cell viability was evaluated using trypan blue exclusion (Jain \& Jasper 1967). The milk cells were then diluted with nutritional medium containing $10 \%$ fetal bovine serum to a concentration of $2 \times 10^{6}$ viable cells $/ \mathrm{mL}$.

Identification of neutrophils. Milk neutrophils were differentiated from other cells by indirect fluorescent labeling. The cells were incubated with an unlabeled primary monoclonal anti-bovine granulocyte antibody (anti-CH138A, VMRD Pullman Inc. Corp ${ }^{\circledR}$, Pullman, USA) for $30 \mathrm{~min}$ at room temperature. Next, $1 \mathrm{~mL}$ of PBS was added to the cell suspension, which was centrifuged at $400 \mathrm{xg}$ for $8 \mathrm{~min}$. Finally, a labeled secondary antibody was added, and the sample was incubated for $30 \mathrm{~min}$ at room temperature in the dark to visualize the bound $\mathrm{CH} 138 \mathrm{~A}$. The neutrophils were identified using flow cytometry based on the cells' cytoplasmic granularities and CH138A positivities as previously described (Piepers et al. 2009, Blagitz et al. 2013). The labeled secondary monoclonal antibodies included allophycocyanin- (APC) (M31505, Invitrogen, Carlsbad, USA) goat anti-mouse IgM antibody. A total of 20,000 milk cells, excluding most of the cellular debris, were examined per sample. The FlowJo software (TreeStar Inc., Ashland, OR, USA) was used to analyze the data. The results were corrected for autofluorescence content, which was defined as the fluorescence that was associated with the non-labeled freshly isolated milk cells from the same quarter.

Intracellular reactive oxygen species production. Intracellular reactive oxygen species (ROS) production was assessed with flow cytometry using 2',7'-dichlorofluorescein diacetate (DCFH-DA) as a probe (Hasui et al. 1989, Blagitz et al. 2013). Briefly, $2 \times 10^{5}$ viable milk cells from each quarter, which was previously assessed using trypan blue exclusion, were incubated at $37^{\circ} \mathrm{C}$ for $30 \mathrm{~min}$ with $0.3 \mu \mathrm{M}$ DCFH-DA (D6883, Sigma Aldrich, St. Louis, MO, USA).

The percentage of neutrophils $\left(\mathrm{CH} 138^{+}\right)$producing ROS was calculated as the number of fluorescent neutrophils divided by the total neutrophil count and multiplied by 100 . The median fluorescence intensity (MFI) of ROS production was estimated from the median of DCF fluorescence (Blagitz et al. 2013, 2015). For this assay, 10,000 gated neutrophils were examined per sample. FlowJo software (TreeStar Inc., Ashland, USA) was used to analyze the data. The results were corrected for autofluorescence, which was defined as the fluorescence that was associated with non-labeled freshly isolated milk cells from the same quarter.

Preparation of PI-labeled bacteria. PI-labeled Staphylococcus aureus (ATCC 25923) was prepared as described by Hasui et al. (1989) with some modifications for the detection of phagocytosis of $S$. aureus by milk neutrophils. Briefly, S. aureus was cultured for $18 \mathrm{~h}$ at $37^{\circ} \mathrm{C}$ on brain-heart infusion agar. Subsequently, the bacteria were heat-killed using incubation at $60^{\circ} \mathrm{C}$ for $30 \mathrm{~min}$, after which they were washed three times using a sterile saline solution $(0.9 \% \mathrm{NaCl})$. The bacterial density was adjusted to an absorbance of 2.50 at $620 \mathrm{~nm}$, yielding approximately $2.4 \times 10^{9}$ bacteria/mL, as previously described. The bacteria were then labeled using a 5\% PI (P4170, Sigma Aldrich, St. Louis, MO, USA) solution for $30 \mathrm{~min}$ on ice. The fluorescent bacteria were washed three times and suspended in PBS containing $5 \mathrm{mM}$ glucose and $0.1 \%$ gelatin, and aliquots were stored at $-80^{\circ} \mathrm{C}$. Thereafter, the PI-labeling of the bacteria was confirmed using flow cytometry.

Phagocytosis assay. The phagocytosis assay was performed using flow cytometry of PI-labeled S. aureus (Hasui et al. 1989, Blagitz et al. 2013, 2015). Briefly, $2 \times 10^{5}$ viable milk cells were incubated with $100 \mu \mathrm{L}$ of heat-killed, PI-labeled S. aureus and $900 \mu \mathrm{L}$ of PBS for $30 \mathrm{~min}$ at $37^{\circ} \mathrm{C}$. Subsequently, $2 \mathrm{~mL}$ of $3 \mathrm{mM}$ EDTA was added, and after centrifugation at $400 \mathrm{xg}$ for $10 \mathrm{~min}$, the leukocytes were resuspended in $300 \mu \mathrm{L}$ of PBS and analyzed using flow cytometry.

The percentage of neutrophils $\left(\mathrm{CH}_{138}{ }^{+}\right)$that phagocytized the PI-labeled bacteria was equal to the number of fluorescent neutrophils divided by the total neutrophil count and multiplied by 100 . The MFI of $S$. aureus phagocytosis was estimated from the median value of PI fluorescence (Blagitz et al. 2013, 2015). At least 20,000 cells were examined per sample. FlowJo Tree Star Software (TreeStar Inc., Ashland, OR, USA) was used to analyze the data.

Statistical analysis. The distributions of all of the variables were examined using normal probability plots obtained using the Kolmogorov-Smirnov test. To compare differences between groups, the Student's t-test was used for data with Gaussian distributions, and Mann-Whitney test was used for nonparametric data. The correlations between logarithm SCC and percentage of milk neutrophils and neutrophils functions were determined by Pearson correlation for data with Gaussian distributions (percentage of neutrophils that phagocytosed $S$. aureus, MFI of ROS production or phagocytosed $S$. aureus by milk neutrophils) or Spearman correlation for nonparametric data ( $\% \mathrm{CH} 138^{+}$neutrophils and percentage of neutrophils that produced ROS). These statistical analysis were performed using GraphPad Prism 6 software ${ }^{\circledR}$ (GraphPad Software, Inc., San Diego, CA, USA). Significance was declared at $P \leq 0.05$ unless otherwise indicated. All statistical analyses to determine the diagnostic characteristics of the tests (area under the receiver operating characteristic (ROC) curve, sensitivity, specificity and Youden index) were performed using Meldcalc statistical software 
(Meldcalc software, Belgium). The SCC threshold of $2 \times 10^{5}$ cells $\mathrm{mL}^{-1}$ was used to determine the predictive values of neutrophil functions to diagnosis mastitis.

\section{RESULTS}

The SCC measurement found 72 samples with SCC $\leq 2 \times 10^{5}$ cells $\mathrm{mL}^{-1}$ and 40 samples with SCC $>2 \times 10^{5}$ cells $\mathrm{mL}^{-1}$. Here, $15.28 \%$ (13.9\% Corynebacterium bovis and 1.4\% Staphylococcus chromogens) and 57.5\% (32.5\% Streptococccus dysgalactiae and $25.0 \%$ Corynebacterium bovis) of the milk samples were microbiologically positive with low and high SCCs, respectively. The flow cytometric analysis validated that a higher percentage of neutrophils was present in higher milk SCC $(P=0.0003)$, and this group also had a significantly higher percentage of neutrophils that produced ROS $(P=0.008)$. On the other hand, the MFI phagocytosis of $S$. aureus by milk neutrophils was higher in quarters with low SCC $(P=0.003)$, which shows a better performance of these types of cell in this group, suggesting a better immunity efficiency. The percentage of phagocytosis of $S$. aureus by milk neutrophils, as well as the MFI of ROS production by milk neutrophils showed no significant difference between the two groups of SCC (Table 1).

Furthermore, there was a positive correlation between the milk SCC and the percentage of neutrophils ( $\mathrm{r}=0.51 ; P \leq 0.0001)$ and the percentage of neutrophils that produced ROS $(r=0.31$; $P=0.001)$. Conversely, there was a negative correlation between the MFI of neutrophils that phagocytozed $S$. aureus and the milk SCC ( $\mathrm{r}=-0.35 ; P=0.0002)$. No significant correlation was observed between milk SCC and the MFI of neutrophils that produced ROS $(\mathrm{r}=-0.09 ; P=0.32)$ and the percentage of neutrophils that phagocytozed $S$. aureus $(\mathrm{r}=0.06 ; P=0.52)$.
The area under the ROC curve and the predictive values of the neutrophil functions that maximized the sensitivity and specificity, indicated by the ROC curve analysis discriminated by the most used SCC threshold $(200,000$ cells $/ \mathrm{mL})$ to detect intramammary infections (IMIs), are shown in Table 2.

\section{DISCUSSION}

The somatic cell count is an important mammary gland inflammatory marker since the majority of the cell subpopulations (i.e. neutrophils) is originated from the blood through the chemotaxis and diapedesis in response to a local aggression (Paape et al. 2003). With this in mind, it is well known that the percentage of neutrophils markedly increased during IMIs (Pyörälä 2003, Mira et al. 2013), as demonstrated here by the positive correlation between the milk SCC and the percentage of milk PMNs. Furthermore, as expected, the quarter milk samples with high SCC had a greater proportion of bacteriologically positive quarters than those with low SCCs in the present study.

We have shown that there is a positive correlation between the percentage of neutrophils that produced ROS and the SCC, reinforced by the lower percentage of neutrophils that produced ROS in milk quarter samples with lower SCC. In this context, our previous results showed that milk samples with higher SCC had higher neutrophil viability (Pessoa et al. 2012). These results can be sustained by the hypothesis that the high proportion of freshly migrated PMN in infected quarters leads to higher viability and independent chemiluminescence activity (ROS quantification) (Mehrzad et al. 2004).

Conversely, the MFI of Staphylococcus aureus phagocytosis is higher in milk quarter samples with lower SCC, suggesting

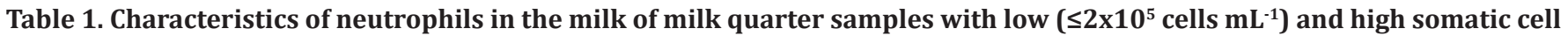
count $\left(>2 \times 10^{5}\right.$ cells $\left.\mathrm{mL}^{-1}\right)$

\begin{tabular}{|c|c|c|c|}
\hline Neutrophil Function/Group & $\begin{array}{c}\mathrm{SCC} \leq 2 \times 10^{5} \text { cells } \mathrm{mL}^{-1} \\
(\mathrm{n}=72)\end{array}$ & $\begin{array}{c}\text { SCC }>2 \times 10^{5} \text { cells } \mathrm{mL}^{-1} \\
(\mathrm{n}=40)\end{array}$ & $P$ value \\
\hline$\% \mathrm{CH}_{138^{+}}$ & $12.57 \pm 12.87^{b}$ & $21.57 \pm 14.72^{\mathrm{a}}$ & 0.0003 \\
\hline ROS production (\%) & $64.77 \pm 22.77^{b}$ & $73.83 \pm 24.18^{\mathrm{a}}$ & 0.008 \\
\hline Intensity of ROS production (MFI) & $1,568 \pm 849.1^{\mathrm{a}}$ & $1,568 \pm 1,045^{\mathrm{a}}$ & 0.99 \\
\hline S. aureus phagocytosis (\%) & $58.60 \pm 17.69^{a}$ & $58.67 \pm 15.98^{\mathrm{a}}$ & 0.72 \\
\hline Intensity of S. aureus phagocytosis (MFI) & $176.5 \pm 89.92^{\mathrm{a}}$ & $125.7 \pm 78.31^{b}$ & 0.003 \\
\hline
\end{tabular}

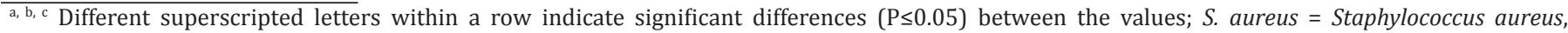
$\mathrm{SCC}=$ somatic cell count, ROS $=$ reactive oxygen species, MFI $=$ median fluorescence intensity. The results are shown as the mean \pm SD.

Table 2. The ROC curve and sensitivity/specificity of neutrophil functions to detect samples with low $\left(\leq 2 \times 10^{5}\right.$ cells $\left.\mathrm{mL}^{-1}\right)$ and high somatic cell count $\left(>2 \times 10^{5}\right.$ cells $\left.\mathrm{mL}^{-1}\right)$

\begin{tabular}{|c|c|c|c|c|}
\hline $\begin{array}{l}\text { Predictive values/ } \\
\text { Neutrophil function }\end{array}$ & ROS production (\%) & $\begin{array}{c}\text { Intensity of ROS production } \\
\text { (MFI) }\end{array}$ & S. aureus phagocytosis (\%) & $\begin{array}{l}\text { Intensity of } S \text {. aureus } \\
\text { phagocytosis (MFI) }\end{array}$ \\
\hline \multicolumn{5}{|c|}{ Receiver operating characteristics (ROC) analysis } \\
\hline Area under ROC curve $(95 \% \mathrm{CI})$ & $0.65 \pm 0.06(0.56-0.74)$ & $0.50 \pm 0.06(0,41-0.60)$ & $0.52 \pm 0.06(0.42-0.62)$ & $0.67 \pm 0.05(0.58-0.76)$ \\
\hline$P$ value & 0.008 & 0.94 & 0.72 & 0.002 \\
\hline Threshold & 80.2 & 491 & 59.9 & 101 \\
\hline Youden index & 0.36 & 0.22 & 0.14 & 0.29 \\
\hline Sensitivity (95\% CI) & $65.00(48.3-79.4)$ & $72.50(56.1-85.1)$ & $57.50(40.9-73.0)$ & $50.00(33.8-66.2)$ \\
\hline Specificity (95\% CI) & $70.83(58.9-81.0)$ & $5.56(1.5-13.6)$ & $56.94(44.7-68.6)$ & $79.17(68.0-87.8)$ \\
\hline
\end{tabular}

$\mathrm{ROC}=$ receiver operating characteristics, SCC = somatic cell count, ROS = reactive oxygen species, MFI = median fluorescence intensity, $95 \%$ CI = 95\% confidence interval. 
a better response and efficiency of neutrophils in the milk quarters samples with lower SCC, reinforced by the negative correlation between this neutrophil function and SCC. With this in mind, variations among cows in neutrophil activity might explain differences in susceptibility of the mammary gland to infection (Paape et al. 2003). Regarding our results, it is possible to measure the presence of the PMNs targeting the immune function, which could help in the development of a new method to select cow with a better immune response, although more studies are necessary. Similarly, to our results, Rivas et al. $(2002,2006)$ have described that MFI phagocytosis of fluorescent beads by milk phagocytes was negatively associated with mastitis. These authors have also suggested that animal selection should favor higher levels of phagocytosis, which may translate as greatest resistance to mastitis and lower SCCs. A low SCC has long been suggested as a goal for breeding practices. However, rather than basing breeding practices only on an indicator, measurement of phagocytosis can facilitate decisions, and consequently should be regarded in breeding practices. Thus, the variability in phagocytosis of $S$. aureus by milk neutrophils found here implies that this immune parameter could be used for the selection of dairy cows with improved mammary gland immune response with beneficial effects to mammary gland health and milk production.

Analyzing the results of the ROC, showed on Table 2, it can be implied that the measured functions cannot be used isolated as a good diagnosis test since none of them had a satisfactory sensitivity and specificity values which is also confirmed in the Youden index values being far from one. The Youden index indicates the performance of a diagnostic test, and its value ranges from zero to one. A value of zero indicates that a diagnostic test provided the same proportion of positive results for groups with and without the disease, and a value of one indicates that no false positives or false negatives were detected (Schisterman et al. 2005).

When making recommendations about a diagnostic test, it is important to consider the consequences of false-negative and false-positive results. In the case of mastitis, the costs of treatment or culling of positive animals are important factors, and the aim is generally to reduce the overall prevalence of infection without necessarily eliminating the disease; therefore, specificity takes priority. However, to eliminate a disease, the sensitivity would have a higher priority than specificity (Souza et al. 2012). Further studies are necessary to evaluate a new diagnosis strategies based for instance on serial testing using both percentage of PMN that produced ROS and the MFI of $S$. aureus phagocytosis activity by PMN shown on Table 2. This kind of analysis allows one factor to improve the specificity of the test, for example, in the present study the specificity of the MFI phagocytosis would be improved by the percentage of PMN that produced ROS, which leads to a fewer number of false negatives at the end of the analysis (specificity=0.86).

\section{CONCLUSIONS}

The assessment of bovine milk neutrophil functions could improve our understanding of the cellular basis of mastitis.

Although the intracellular ROS production and Staphylococcus aureus phagocytosis by milk neutrophil did not have high predictive values to detect IMIs (i.e. milk quarter samples with high somatic cell count (SCC), our results strengthen the idea that poor bovine mammary gland neutrophil phagocytic ability may be associated with high SCC, and the variability in this neutrophil function might be considered in breeding practices in attempt to improve mammary gland resistance to mastitis.

Acknowledgements.- This study was supported by Fundação de Amparo à Pesquisa do Estado de São Paulo (Project No. 2009/50672-0). AMMPDL is indebted to CNPq for her fellowship. FNS and PCCM are also indebted to FAPESP for their fellowships.

\section{REFERENCES}

Blagitz M.G., Souza F.N., Batista C.F., Azevedo L.F., Benites N.R., Melville P.A., Diniz S.A., Silva M.X., Haddad J.P., Heinnemann M.B., Cerqueira M.M. \& Della Libera A.M. 2015. The neutrophil function and lymphocyte profile of milk from bovine mammary glands infected with Streptococcus dysgalactiae. J. Dairy Res. 82(4):460-469. http://dx.doi.org/10.1017/S0022029915000308. PMid:26119656.

Blagitz M.G., Souza F.N., Santos B.P., Batista C.F., Parra A.C., Azevedo L.F., Melville P.A., Benites N.R. \& Della Libera A.M. 2013. Function of milk polymorphonuclear neutrophil leukocytes in bovine mammary glands infected with Corynebacterium bovis. J. Dairy Sci. 96(6):3750-3757. http:// dx.doi.org/10.3168/jds.2012-6370. PMid:23608489.

Della Libera A.M.M.P., Souza F.N., Blagitz M.G. \& Batista C.F. 2011. Avaliação de indicadores inflamatórios no diagnóstico da mastite. Arqs Inst. Biológico, São Paulo 78:297-300.

Hasui M., Hirabayashi Y. \& Kobayashi Y. 1989. Simultaneous measurement by flow cytometry of phagocytosis and hydrogen peroxide production of neutrophils in whole blood. J. Immunol. Methods 117(1):53-58. http:// dx.doi.org/10.1016/0022-1759(89)90118-X. PMid:2913161.

Jain N.C. \& Jasper D.E. 1967. Viable cells in bovine milk. Brit. Vet. J. 123(2):5763. http://dx.doi.org/10.1016/S0007-1935(17)40154-0.

Koess C. \& Hamann J. 2008. Detection of mastitis in the bovine mammary gland by flow cytometry at early stages. J. Dairy Res. 75(2):225-232. http:// dx.doi.org/10.1017/S0022029908003245. PMid:18474141.

Laevens H., Deluyker H., Schukken Y.H., Meulemeester L., Vandermeersch R., Muêlenaere E. \& Kruif A. 1997. Influence of parity and stage of lactation on somatic cell count in bacteriologically negative dairy cows. J. Dairy Sci. 80(12):3219-3226. http://dx.doi.org/10.3168/jds.S0022-0302(97)762957. PMid:9436102.

Mehrzad J., Duchateau L. \& Burvenich C. 2004. Viability of milk neutrophils and severity of bovine coliform mastitis. J. Dairy Sci. 87(12):4150-4162. http://dx.doi.org/10.3168/jds.S0022-0302(04)73558-4.PMid:15545377.

Mira C.S., Della Libera A.M.M.P., Souza F.N. \& Blagitz M.G. 2013. Correlação entre a contagem automática de células somáticas e a porcentagem de neutrófilos pela citometria de fluxo e pela técnica de citocentrifugação. Arq. Bras. Med. Vet. Zootec. 65(5):1403-1408. http://dx.doi.org/10.1590/ S0102-09352013000500019.

NRC 2001. Nutrient Requirements of Dairy Cattle. 7th ed. National Research Council, The National Academies Press, Washington. 381p.

Oliver S.P., González R.N., Hogan J.S., Jayarao B.N. \& Owens W.E. 2004. Microbiological procedures for the diagnosis of bovine udder infection and determination of milk quality. National Mastitis Council, Verona. 47p.

Paape M.J., Bannerman D.D., Zhao X. \& Lee J.W. 2003. The bovine neutrophil: structure and function. Vet. Res. 34(5):597-627. http://dx.doi.org/10.1051/ vetres:2003024. PMid:14556697.

Pessoa R.B., Blagitz M.G., Batista C.F., Santos B.P., Parra A.C., Souza F.N. \& Libera A.M.M.P.D. 2012. Avaliação da apoptose de leucócitos polimorfonucleares 
CH138+ em leite bovino de alta e baixa contagem de células somáticas: dados preliminares. Arq. Bras. Med. Vet. Zootec. 64(3):533-539. http:// dx.doi.org/10.1590/S0102-09352012000300002.

Piepers S., De Vliegher S., Demeyere K., Lambrecht B.N., Kruif A., Meyer E. \& Opsomer G. 2009. Technical note: flow cytometric identification of bovine milk neutrophils and simultaneous quantification of their viability. J. Dairy Sci. 92(2):626-631. http://dx.doi.org/10.3168/jds.2008-1393. PMid:19164674.

Pyörälä S. 2003. Indicators of inflammation in the diagnosis of mastitis. Vet. Res. 34(5):565-578. http://dx.doi.org/10.1051/vetres:2003026. PMid:14556695.

Rivas A.L., Tadevosyan R., Gorewit R.C., Anderson K.L., Lyman R. \& González R.N. 2006. Relationship between the phagocytic ability of milk macrophages and polymorphonuclear cells and somatic cell counts in uninfected cows. Can. J. Vet. Res. 70(1):68-74. PMid:16548336.

Rivas A.L., Tadevosyan R., Quimby F.W., Coksaygan T. \& Lein D.H. 2002. Identification of subpopulations of bovine mammary-gland phagocytes and evaluation of sensitivity and specificity of morphologic and functional indicators of bovine mastitis. Can. J. Vet. Res. 66(3):165-172. PMid:12146888.

Schepers A.J., Lam T.J., Schukken Y.H., Wilmink J.B. \& Hanekamp W.J. 1997. Estimation of variance components for somatic cell counts to determine thresholds for uninfected quarters. J. Dairy Sci. 80(8):1833-1840. http:// dx.doi.org/10.3168/jds.S0022-0302(97)76118-6. PMid:9276824.

Schisterman E.F., Perkins N.J., Liu A. \& Bondell H. 2005 Optimal cut-point and its corresponding Youden Index to discriminate individuals using pooled blood samples. Epidemiology 16(1):73-81. http://dx.doi.org/10.1097/01. ede.0000147512.81966.ba. PMid:15613948.

Schukken Y.H., Wilson D.J., Welcome F., Garrison-Tikofsky L. \& Gonzalez R.N. 2003. Monitoring udder health and milk quality using somatic cell counts. Vet. Res. 34(5):579-596. http://dx.doi.org/10.1051/vetres:2003028. PMid:14556696.

Souza F.N., Blagitz M.G., Penna C.F.M.A., Della Libera A.M.M.P., Heinemann M.B. \& Cerqueira M.M.O.P. 2012. Somatic cell count in small ruminants: friend or foe? Small Rumin. Res. 107(2-3):65-75. http://dx.doi.org/10.1016/j. smallrumres.2012.04.005. 